\title{
Leukocyte Adhesion Deficiency Associated with Neona- tal Septic Hip in a Late Preterm Infant
}

Hye-Eun Kim, Do Hee Kim, Sung-Hoon Chung, Chong-Woo Bae, and Yong-Sung Choi

Department of Pediatrics, Kyung Hee University School of Medicine, Seoul, Korea

\section{ABSTRACT}

Leukocyte adhesion deficiency is a rare primary immunodeficiency and autosomal recessive disorder caused by a mutation in the gene encoding CD18, which is a constituent of leukocyte integrins. Clinical features usually begin with a delay in the separation of the umbilical cord in the neonatal period, and are characterized by marked leukocytosis with infection, delayed wound healing, and repeated bacterial and fungal infections. We experienced a case of leukocyte adhesion deficiency diagnosed in the neonatal period, in which a late preterm infant admitted to neonatal intensive care unit presented with a septic hip. Flow cytometry analysis of whole blood showed a decrease in the expression of CD11b/CD18. This is the first case of leukocyte adhesion deficiency with neonatal septic hip diagnosed in Korea.

Key Words: Leukocyte adhesion deficiency, Infectious arthritis, Osteomyelitis, Premature infant

서론

백혈구부착결핍증(leukocyte adhesion deficiency, LAD)은 드문 일차성 면역결핍 질환이며 상 염색체 열성 질환으로 백혈구의 32 인테그린(integrin) 단백질인 CD18을 암호화하는 유전자의 변이로 인해 발생한다. $\mathrm{CD} 18$ 의 발현 감소 또는 기능 부전으로 인해 백혈구가 혈관벽에 부착하 는 과정에 심각한 어려움이 생기며 감염과 염증 부위로 백혈구 이동이 제한되고, 생명을 위협하 는 세균 및 진균 감염이 반복적으로 일어나게 된다 ${ }^{1-3)}$. 이 질환은 1979 년에 제대 탈락의 지연, 호 중구 증가증, 전신적인 세균 감염이 동반된 환자에서 처음 보고되었으며), 증상은 보통 신생아 시기 제대 탈락이 지연되는 것부터 시작되며 감염 시 상처 치유가 지연되고 백혈구 수치가 강하 게 증가하는 것이 특징이다. 집중적인 항생제 치료에도 어린 나이에 사망하는 경우가 많고 최선 의 치료법은 골수이식으로 알려져 있다 ${ }^{2)}$.

신생아 및 영아의 화농성 관절염은 치료하지 않으면 심각한 후유증을 유발할 수 있는 중증의 감염성 질환이며) 어린 영아에서의 진단은 성인의 경우보다 어렵다.). 가장 흔한 원인균은 메티 실린 내성 포도상구균(methicillin-resistant Staphylococcus aureus, MRSA)이고 무릎 관절과 고관 절에 가장 많이 발생하며 조기 진단 및 적절한 항생제 치료와 관절천자나 수술을 통한 조기 배농 이 중요하다 ${ }^{5,7)}$.
Received: 24 July 2018

Revised: 13 September 2018

Accepted: 14 September 2018

Correspondence to: Yong-Sung Choi Department of Pediatrics, Kyung Hee University School of Medicine, 23 Kyungheedae-ro, Dongdaemungu, Seoul 02447, Korea

Tel: +82-2-958-2921

Fax: +82-2-958-8304

E-mail: feelhope@khu.ac.kr

Copyright(c)

By Korean Society of Neonatology.

All right reserved.

This is an Open-Access article distributed under the terms of the Creative Commons Attribution Non-Commercial License (http://creativecommons.org/licenses/ by-nc/4.0), which permits unrestricted non-commercial use, distribution, and reproduction in any medium, provided the original work is properly cited. 
본 저자들은 신생아중환자실에 입원해있던 후기 미숙아 환자에 서 원인이 잘 설명되지 않는 패혈증성 고관절 관절염이 갑작스럽게 발병하여 면역결핍 검사를 시행한 결과, $\mathrm{LAD}$ 가 발견된 증례를 경험 하였기에 이를 보고하는 바이다.

\section{증례}

미숙아 및 저체중 출생아로 신생아중환자실에 입원해 있던 남자 환아로 생후 12 일째 갑작스런 오른쪽 허벅지 종창과 발적이 발생하 였다. 재태 주수 34 주 1 일에 출생 체중 $2,158 \mathrm{~g}$ 으로 본원 산부인과에 서 제왕절개로 출생하였고 아프가 점수는 1 분 8 점, 5 분 9점으로 출 생 시 분만 손상 없이 상태 양호하였으나 후기 미숙아 및 저체중 출 생아로 출생 직후 본원 신생아중환자실로 입원하였다.

환아 출생 시 산모는 27세로 산과력은 만조유생 0-0-0-0로 초산모 였으며, 과거력상 특이 병력 및 약물 복용력은 없었으나 짧은 경부

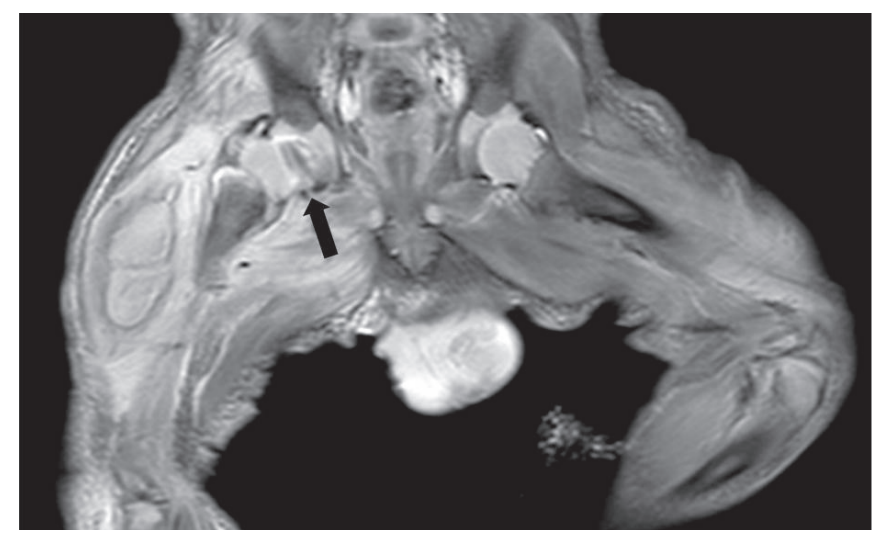

Figure 1. Hip magnetic resonance imaging shows septic arthritis of the right hip associated with periarticular abscess formation in the $\mathrm{T} 2$ coronal section (black arrows).
길이 (short cervix $1.5 \mathrm{~cm}$ ) 및 조기 진통으로 임신 31주 1 일에 본원 산 부인과로 전원 되었다. 입원하여 자궁수축억제제(ritodrine)를 투여 하였으나 임신 34 주 1 일에 양막 파수되어 분만 진행 중 아두골반불 균형(cephalopelvic disproportion)이 있어 응급 제왕절개를 시행하 였다. 가족력 상 진단된 면역결핍 질환 및 유전 질환력 없었고, 근친 결혼 여부도 없었다.

신생아중환자실 입원 후 간헐적으로 발생하는 미숙아 무호흡 이 외에 활력 징후 양호했으며 상기 증상 발생 전까지 기계적 환기요법 및 중심 정맥 혹은 동맥관 시행력 없었다. 말초 정맥관은 구강 수유 가 원활하기 전인 출생 6 일째까지 유지하였으며 하지 부위 정맥관 삽입력 없었고, 출생 12 일째 증상 발생 이전까지 요골동맥을 통한 채혈이 총 5 회 있었다. 제대는 생후 2 주 내에 탈락하였고, 배꼽염 발 생은 없었다.

출생 12 일째 증상 발생 당시 활력 징후는 혈압 $66 / 40 \mathrm{~mm} \mathrm{Hg}$, 맥 박수 154 회/분, 호흡 60 회/분, 체온 $37^{\circ} \mathrm{C}$, 산소포화도 $99 \%$ 였으며, 신 체 검진 시 오른쪽 허벅지 전체적으로 종창과 발적, 압통, 열감이 관 찰되었고 고관절 운동에 제한은 없었다. 증상 발생 다음 날에 오른 쪽 허벅지 둘레는 점차 증가하였고 종창은 범위가 더 넓어져 무릎 아 래까지 퍼졌으며 발적과 열감이 지속하였다. 이외의 이상 소견은 발 견되지 않았다.

증상 발생 당일 시행한 말초혈액검사에서 백혈구 수 $32,270 / \mu \mathrm{L}$ (중성구 $80 \%$, 림프구 $10 \%$, 단핵구 $7 \%$ ), 혈색소 $15.0 \mathrm{~g} / \mathrm{dL}$, 혈소판 $415,000 / \mu \mathrm{L}, \mathrm{C}$-반응단백 $12.90 \mathrm{mg} / \mathrm{dL}$ (정상 0.3 미만) 소견을 보였 고, 동맥혈 가스분석검사상 $\mathrm{pH} 7.519, \mathrm{PCO}_{2} 22.2 \mathrm{~mm} \mathrm{Hg}, \mathrm{PO}_{2} 84$ $\mathrm{mm} \mathrm{Hg}, \mathrm{HCO}_{3}{ }^{-} 18.1 \mathrm{mmol} / \mathrm{L}$, 염기과잉(base excess) $-5 \mathrm{mmol} / \mathrm{L}$ 로 호흡성 알칼리혈증을 보였다. 빼 스캔검사에서 연부조직 부종 소견 이 보였으나 뼈 병변은 관찰되지 않았다. 증상 발생 이틀째 시행한 초음파에서는 오른쪽 고관절의 관절액 증가와 연부조직 부종, 근육 내 혈종 소견이 관찰되었고, 자세한 평가를 위해 시행한 고관절 자기

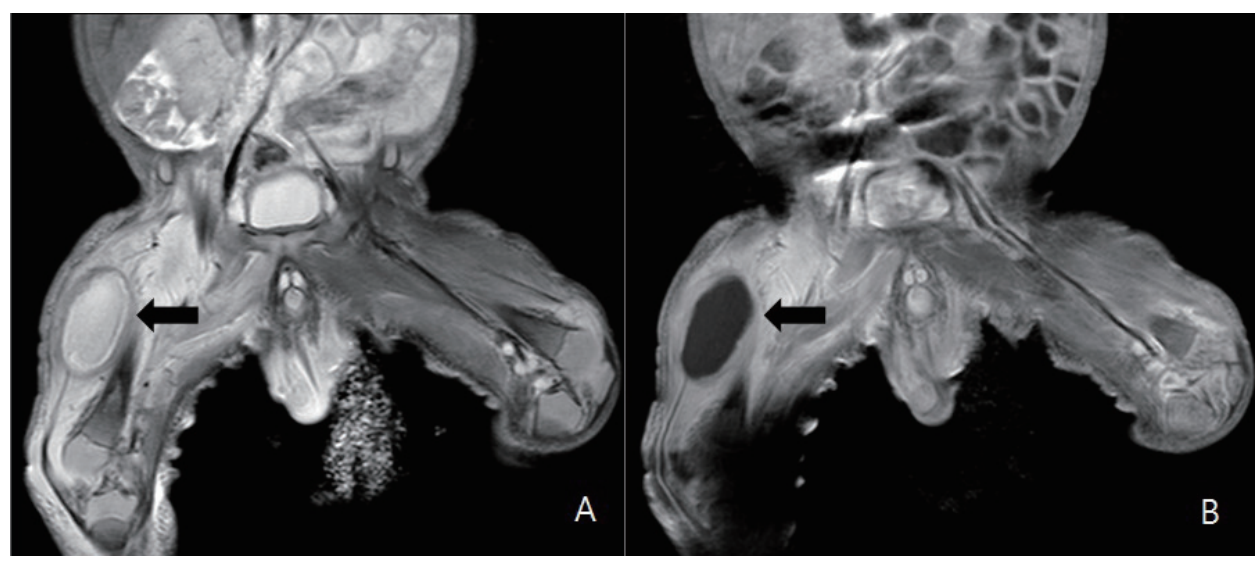

Figure 2. Hip magnetic resonance imaging shows large intramuscular abscess formation in the right anterior thigh, probably vastus intermedius (about $32 \times 28 \times 19 \mathrm{~mm}$ in size) in the (A) T2 and (B) $\mathrm{T} 1$ coronal section (black arrows). 
공명영상(magnetic resonance imaging, MRI) 에서 고관절 주위 농양 형성(Figure 1)과 동반되어 중간넓은근(vastus intermedius)으로 상 당한 양의 근육 내 농양 형성 $(32 \times 28 \times 19 \mathrm{~mm})$ 이 발견되어 고관절 화 농성 관절염(septic arthritis of hip) 소견을 보였다(Figure 2).

치료로 허벅지 종창 발생 직후 연조직염(cellulitis) 의심 하에 나 프실린(nafcillin)과 세포탁심(cefotaxime)을 정맥 내 투여하였으며, $\mathrm{MRI}$ 에서 화농성 관절염 소견이 확인된 후 정형외과와 협진하여 증 상 발생 3 일 째 응급 절개배농술을 시행하였다. 수술 중 오른쪽 허벅 지 전방 부위에서 탁한 암녹색의 점성을 보이는 농양을 배농하였고 이는 오른쪽 고관절과 이어진 것으로 보였다. 증상 당일 시행한 말 초혈액 배양 검사에서 그람양성구균(gram positive cocci)이 확인되 어 증상 3 일 째부터 반코마이신(vancomycin)으로 항생제를 변경하 여 투여하였으며 말초혈액배양 및 수술 시 배농한 농양배양검사에 서 모두 MRSA가 최종 확인되었다.

수술 직후 시행한 말초혈액검사에서 백혈구 수 $11,660 / \mu \mathrm{L}$ (중성구 $67 \%$ ), C-반응단백 $7.22 \mathrm{mg} / \mathrm{dL}$ 로 호전 양상 보였으며 이후 반코마이 신 항생제 치료를 지속 중, 증상 발생 6일째 시행한 혈액배양검사에 서 더 이상 균은 동정 되지 않았다. 수술 12 일째까지 수술 부위에서 갈색 양상의 삼출물이 베어 나와 상처 치유 지연이 관찰되었으나 수 술 부위 감염의 증거는 없었다. 이후 증상 발생 16 일째(수술 14 일째) $\mathrm{C}$-반응단백 $0.3 \mathrm{mg} / \mathrm{dL}$ 미만으로 정상화된 것을 확인하였다.

신생아 시기에 갑작스런 침습적 세균 감염과 화농성 관절염이 발 생하였고, 특히 말초 정맥관을 제거한 지 6일 후에 발생한 특징 때 문에 면역학적 기능 평가를 위해 검사 진행하였다. 면역글로불린 및 보체 검사(IgG/A/M, IgG subclass C3, C4, CH50), 면역세포검사 (NK/B/T cell, CD4/CD8 ratio)에서는 특이 소견 없었고, 중성구 내 호흡폭발검사(respiratory burst of neurophil DHR test) 에서도 정 상 소견을 보였다. 이후 전혈을 채취하여 시행한 유세포 분석 백 혈구 부착 결핍 검사(LAD test, CD11b/CD18 flow cytometry)에서 $\mathrm{CD} 11 \mathrm{~b} / \mathrm{CD} 18$ 의 발현이 정상 대조군에 비해 $19 \%$ 로 감소되어 있는 것이 관찰되었고 이는 $\mathrm{LAD}$ 를 시사하는 소견이었으며 환아는 $\mathrm{LAD}$

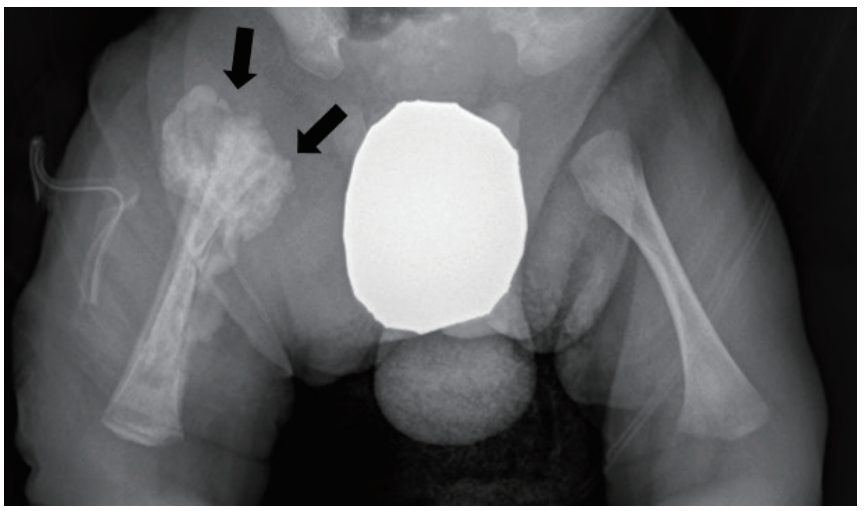

Figure 3. Hip X-ray shows the deformity of the right femoral head (black arrows).
중 유형 1 (type 1)의 중등도 표현형(moderate phenotype)에 속하였 다.

증상 발생 후 12 일째(수술 10 일째) 시행한 방사선검사에서 오른 쪽 대퇴골두의 변형이 관찰되었고(Figure 3), 증상 16 일째 시행한 고 관절 초음파에서는 더 이상의 관절액 집적 소견이나 농양 형성 소 견은 없었으나 이후 추적 시행한 방사선검사상 오른쪽 대퇴골두의 경화성 변형이 진행되는 소견을 보여 증상 23 일째 뼈 스캔검사까 지 시행하였다. 뼈 스캔검사에서 오른쪽 대퇴골과 장골에 골수염 (osteomyelitis) 소견(Figure 4)이 확인되어 투여 중이던 반코마이신 치료 기간을 총 8주까지 지속하기로 계획하였다.

추적 검사를 위해 증상 30 일째(수술 28일째) MRI를 재시행하였 고 화농성 관절염 소견은 호전되었으나 대퇴골 골수염이 남아있는 소견 확인되어 항생제 치료를 지속하였다(Figure 5). 이후 방사선 추 적 검사상 대퇴골두의 미란성 병변은 계속 심화하였고 이에 대퇴골 두전위(femoral head dislocation) 교정을 위하여 파블릭 장구(Pavlik harness)를 적용하여 고관절 외전(abduction) 자세로 고정 치료하였 다. 총 8 주간의 반코마이신 치료 완료 후 환아의 전신적인 신체 컨디 션 및 활력 징후는 양호하며 말초혈액검사상 감염 및 염증 소견 보이 지 않아 증상 56일째(수술 54일째) 파블릭 장구를 적용한 상태로 소 아청소년과 및 정형외과 외래에서 추적 검사를 시행하기로 하고 퇴 원하였다.

\section{고찰}

$\mathrm{LAD}$ 는 신생아기에 제대 탈락의 지연이 있고 이후 심한 감염이 재 발하는 환자에서 의심되어야 할 희귀 질환이다. 이 질환은 백혈구의 인테그린에 공유되는 CD18을 암호화하는 염색체 21q22.3에 위치한 유전자의 변이에 기인하게 된다 ${ }^{1,8)}$. 감염은 일반적으로 출생 이후부
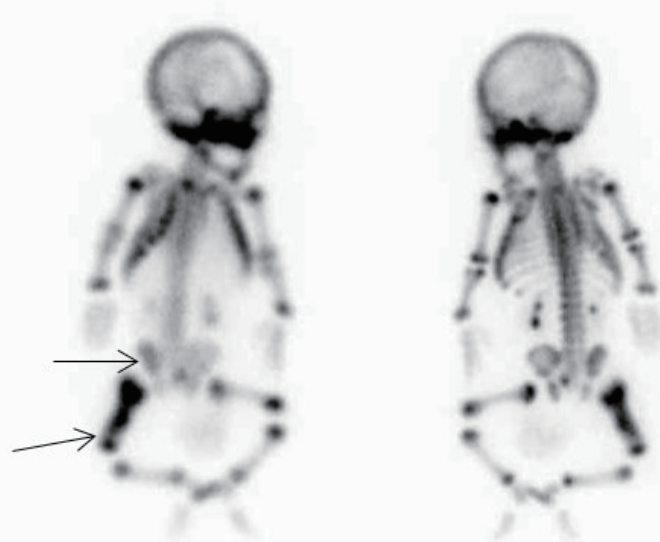

Figure 4. Bone scan shows diffuse uptake in the right femur and right iliac bones (arrows) 


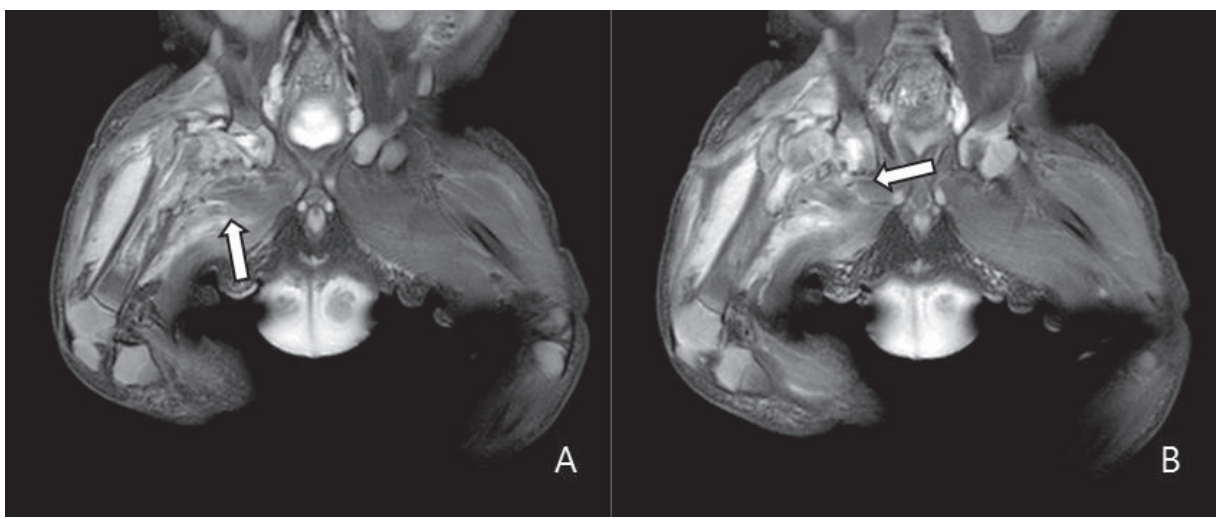

Figure 5. (A, B) Bone scan shows diffuse uptake in the right femur and right iliac bones (arrows).

터 발생하며 가장 흔히 처음 겪게 되는 감염은 제대 탈락의 지연으로 인한 배꼽염(omphalitis)이다 ${ }^{1,2,9)}$. 특징적인 임상 양상으로는 감염 시 혈중 호중구 수의 증가, 상처 치유의 지연, 다균 감염이 있는 만성 궤양, 제대 감염, 심각한 치은염 및 재발하는 세균 및 진균 감염을 포 함한다 ${ }^{10)}$.

$\mathrm{LAD}$ 의 유형에는 현재까지 밝혀진 세 가지의 유형(type 1,2,3 variant)이 있으며 이 중 type 1 이 가장 흔한 형태이고 이 형태에서 유 전자의 돌연변이는 $\beta 2$ 인테그린을 암호화하는 $21 \mathrm{q} 22.3$ 에 위치한 $\beta 2$ 인테그린 소단위(integrin $\beta$ subunit 2, ITGB2)에서 발견된다. 이 는 백혈구 표면에서의 $\beta 2$ 인테그린 발현의 결핍 또는 감소를 유도하 지만 때로는 비기능성 인테그린의 정상 발현으로 발견되기도 한다. Type 2 와 type 3 는 매우 드물며 type 2 를 가진 환자는 세포 표면 당 단백질의 퓨코실레이션(fucosylation)에 결함이 생긴다. 이에 의해 $\beta 2$ 인테그린 활성화의 한 메커니즘이 부족하게 되어 혈관벽으로의 백혈구 부착이 감소하고 조직으로의 이동이 감소하게 된다. 그러나 케모카인 및 T 세포 수용체 경로는 유효하여 type 2 의 LAD 환자의 감염은 일반적으로 type 1 보다 경하게 발생한다. 마지막으로 type 3 환자들은 $\beta 2$ 인테그린의 발현량은 정상이나 인테그린을 배위자 (ligand)에 결합시키는 데에 필요한 “내부-외부” 신호 전달에 결함이 있다고 관찰되었고 이 결함은 최근 11q13.1 에 위치한 유전자의 돌 연변이로 밝혀졌다. Type 3 환자는 반복적인 출혈이 특징적으로 나 타나는데 혈소판의 인테그린 장애 또한 동반되기 때문이다 ${ }^{1,11}$.

본 증례의 환자는 출생 이후 제대 탈락의 지연 및 배꼽염은 발생하 지 않았으나 출생 12 일째 MRSA에 의한 패혈증 및 화농성 관절염이 발생하였고 세포분석 면역검사상 백혈구의 CD18 발현이 감소한 것 을 통해 LAD type 1 이 진단되었다. 많은 $\mathrm{LAD}$ 환자는 집중적인 항생 제 치료에도 불구하고 어린 나이에 사망하는 경우가 많으나 ${ }^{2}$ 본 증 례의 환자는 조기에 감수성 있는 항생제 치료에 의해 화농성 관절염 및 패혈증은 치료되었고 골수염에 의한 후유증은 남게 되었다.

$\mathrm{LAD}$ 환자에서 감염성 합병증의 중증도는 $\mathrm{CD} 18$ 결핍의 정도와 직 접적으로 관련이 있는 것으로 알려졌다. $\mathrm{CD} 18$ 의 부분적 발현이 있
는 환자는 경증 내지 중등도의 표현형을 나타내며, 심각한 감염의 발 병이 적고 성인기까지 생존한다. 반면 중증의 LAD에서는 백혈구 세 포 표면의 CD18/CD11A, CD11B 및 CD11C 분자의 발현이 부족하 게 되고, 조기에 줄기세포 이식 치료를 하지 못하면 출생 첫해 이내 에 사망하게 된다 ${ }^{1,2,8,12)}$. 본 증례의 환자는 정상 백혈구의 $19 \%$ 정도 의 CD18 일부 표면 발현이 있었기에 중등도의 표현형을 가진 것으 로 사료되었고 이는 이번 감염으로 사망까지 이르지 않은 것과 연관 이 있을 것이다.

본 증례의 경우 고관절 화농성 관절염 이후 대퇴골 골수염이 발생 하였다. 어린 영아의 화농성 관절염에서 가장 흔하게 침범되는 관절 은 무를 관절 다음으로 고관절로 알려져 있다. 가장 흔한 원인균은 MRSA이며 선행 요인으로는 저체중 출생아, 미숙아, 빈혈, 이전의 입 원 및 침습적인 시술로 보고되고 있다,7). 증례의 환자 또한 가장 흔 한 원인균인 MRSA가 말초혈액과 고관절 농양에서 배양되었으며 가 지고 있는 위험요인으로 저체중 출생아, 미숙아, 신생아중환자실에 입원 중인 것을 들 수 있었다. 고관절은 자주 관여하는 부위이지만 가장 불량한 예후를 나타낸다고 보고되었으며 대퇴골 골수염의 합 병증을 유발할 수 있다고 되어있다 ${ }^{13)}$.

항생제 치료는 화농성 관절염 및 급성 골수염의 최선의 치료이다. 최근에는 합병증이 없는 화농성 관절염에서 경구 항생제를 포함한 2 주간의 항균 요법이 추천되고 골수염에는 3 주간의 항균 요법이 권장 되고 있으며, 합병증이 동반된 화농성 관절염에는 최소 3 주, 골수염 에서는 4 주에서 6 주 동안 정맥 내 치료를 지속하는 것이 권장되고 있 다. 본 증례의 환자에서는 패혈증성 화농성 관절염과 골수염 합병증 이 동반되어 총 8주간의 치료를 계획하였고 신생아에서 사용 가능한 반코마이신 경구제제가 없어 정맥 투여로 치료를 지속하였다. 신생 아의 골반 골수염 치료에 정확한 지침은 없으나 최근의 한 증례에서 는 4주간의 항생제 정맥 투여 이후 4주간의 경구 투여로 성공적으로 치료된 신생아 골수염의 경우를 보고하였다 ${ }^{14-16)}$.

본 저자들의 문헌 검색에 의하면 $\mathrm{LAD}$ 를 가진 신생아에서 고관절 화농성 관절염과 골수염이 발생한 증례가 국내에서는 처음 보고되 
는 것이다. 특히 신생아 시기에 $\mathrm{LAD}$ 가 진단된 경우는 더욱 흔치 않 은 증례이다. 본 증례 환자의 경우 조기 항생제 치료와 수술적 치료 를 통해 치명적인 합병증은 예방하였지만, 골수염에 동반된 골변형 후유증은 막지 못하였다. LAD와 같은 일차성 면역결핍 질환이 있는 환자에서는 감염에 의한 치사율이 높으므로 주의 깊은 관찰이 필요 하다. 신생아 시기부터 감염이 반복되었으며 적절한 항생제 투여에 도 불구하고 치료에 잘 반응하지 않는 환자를 임상에서 직면하였을 때 $\mathrm{LAD}$ 와 같은 면역결핍 질환의 가능성을 항상 고려해야 할 것이다.

\section{REFERENCES}

1. van de Vijver E, Maddalena A, Sanal O, Holland SM, Uzel G, Madkaikar M, et al. Hematologically important mutations: leukocyte adhesion deficiency (first update). Blood Cells Mol Dis 2012;48:53-61.

2. Hanna S, Etzioni A. Leukocyte adhesion deficiencies. Ann NY Acad Sci 2012;1250:50-5.

3. Lorusso F, Kong D, Jalil AK, Sylvestre C, Tan SL, Ao A. Preimplantation genetic diagnosis of leukocyte adhesion deficiency type I. Fertil Steril 2006;85:494.

4. Hayward AR, Harvey BA, Leonard J, Greenwood MC, Wood CB, Soothill JF. Delayed separation of the umbilical cord, widespread infections, and defective neutrophil mobility. Lancet 1979;1:1099-101.

5. Kabak S, Halici M, Akcakus M, Cetin N, Narin N. Septic arthritis in patients followed-up in neonatal intensive care unit. Pediatr Int 2002;44:652-7.

6. Castellazzi L, Mantero M, Esposito S. Update on the management of pediatric acute osteomyelitis and septic arthritis. Int J Mol Sci 2016;17:E855.
7. Sankaran G, Zacharia B, Roy A, Purayil SP. Current clinical and bacteriological profile of septic arthritis in young infants: a prospective study from a tertiary referral centre. Eur J Orthop Surg Traumatol 2018;28:573-8.

8. Hogg N, Henderson R, Leitinger B, McDowall A, Porter J, Stanley P. Mechanisms contributing to the activity of integrins on leukocytes. Immunol Rev 2002;186:164-71.

9. Wada T, Tone Y, Shibata F, Toma T, Yachie A. Delayed wound healing in leukocyte adhesion deficiency type 1. J Pediatr 2011;158:342.

10. Mathew EC, Shaw JM, Bonilla FA, Law SK, Wright DA. A novel point mutation in CD18 causing the expression of dysfunctional CD11/CD18 leucocyte integrins in a patient with leucocyte adhesion deficiency (LAD). Clin Exp Immunol 2000;121:133-8.

11. Kang HJ, Shin HY, Ahn HS. Recent advance in primary immune deficiency disorders. Korean J Pediatr 2009;52:649-54.

12. Kavehmanesh Z, Matinzadeh ZK, Amirsalari S, Torkaman M, Afsharpayman S, Javadipour M. Leukocyte adhesion deficiency: report of two family related newborn infants. Acta Med Iran 2010;48:273-6.

13. Lee SC, Shim JS, Seo SW, Lee SS. Prognostic factors of septic arthritis of hip in infants and neonates: minimum 5-year followup. Clin Orthop Surg 2015;7:110-9.

14. Agarwal A, Aggarwal AN. Bone and joint infections in children: acute hematogenous osteomyelitis. Indian J Pediatr 2016;83: 817-24.

15. Bulbul A, Okan F, Yekeler E, Can E. Acute osteomyelitis of the iliac bone presenting with gluteal syndrome in a newborn. Eur J Pediatr 2009;168:1529-32.

16. Davidson D, Letts M, Khoshhal K. Pelvic osteomyelitis in children: a comparison of decades from 1980-1989 with 1990-2001. J Pediatr Orthop 2003;23:514-21. 